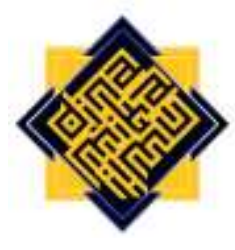

\title{
Challenges in Using WhatsApp as An Online Arabic Learning Center
}

\author{
A. Syahid Robbani \\ Arabic Education Study Program Universitas Ahmad Dahlan, Yogyakarta \\ e-mail:syahidrobbani5@gmail.com
}

Zulfa Amalia Wahidah

Arabic Education Study Program Universitas Islam Negeri Sunan Kalijaga, Yogyakarta

e-mail:zamalia.wahidah@gmail.com

\author{
Ahmad Muzayyan Haqqy \\ Universitas Islam Negeri Mataram \\ e-mail:muzayyan.haqqy@gmail.com
}

\begin{abstract}
This study examined the challenges and obstacles faced in using WhatsApp as an online Arabic learning center and efforts to overcome them. The data from this qualitative study were obtained from observations of 71 students and 2 Arabic language teachers. The data was then validated and strengthened by interviews with five students and 2 Arabic language teachers. The results of this study showed that the challenges and obstacles in using WhatsApp as an online Arabic learning center did not only come from students, student guardians, and teachers but can also come from the limitations of the WhatsApp application itself, such as the maximum file size limit that can be sent and the record button prone to be canceled. In overcoming the existing obstacles, the teacher converts the files to be sent first, lowers the level of questions in assignments, pays attention to the accuracy of students' answers in doing assignments, and collaborates WhatsApp with Google Drive and Instagram. Finally, by looking at the role of the WhatsApp application in the current learning process, the researcher hopes that the WhatsApp application developer will consider providing WhatsApp for Education like WhatsApp for Business which has existed for a long time.
\end{abstract}

Keywords: Arabic Learning, Online Learning, WhatsApp 


\section{A. Syahid Robbani et al.}

\section{A. Introduction}

Learning media is everything that can be used to deliver messages from the sender to the recipient to stimulate students' thoughts, feelings, attention, interests, and willingness in such a way that the learning process occurs to achieve learning objectives effectively (Sukiman, 2010). Media use in Arabic learning is needed to make the learning process more comfortable and become a fun learning activity for students (Sukamto et al., 2017). Learning media is one of the factors that can affect the learning process and other factors such as learning instruments, learning methods, and evaluation and assessment (Anah, 2020). Moreover, learning media plays an essential role in helping teachers to present the material to be taught. The use of appropriate learning media will undoubtedly raise the enthusiasm and motivation of students in learning. It also determines how much learning materials can be delivered and then absorbed and understood by students.

Among the electronic devices that can be used to facilitate online Arabic learning are smartphones, laptops, and computers. More specifically, teachers and students can access applications or websites through these devices such as WhatsApp, Zoom Meeting, Google Classroom, Youtube, E-learning, Moodle, Open Learning, Microsoft Team, or other applications and websites that can be used as learning media. Teachers can combine several existing applications and websites to use in online Arabic learning. However, teachers must also consider and pay attention to the extent of students' abilities and readiness, both related to the ownership of smartphones or laptops, internet quotas, and network strength to access applications or websites because each application and website requires a different internet network quota and strength.

Some of the applications and websites that have been mentioned above certainly have their advantages and disadvantages. These advantages and disadvantages can be used for consideration in the selection of online Arabic learning media. Some of the advantages and disadvantages of each media can be seen in the following table:

Table 1: Advantages and Disadvantages of Online Arabic Learning Media

\begin{tabular}{|c|c|c|c|}
\hline No & Media & Advantages & Disadvantage \\
\hline 1 & WhatsApp & $\begin{array}{l}\text { 1. Cheap and save internet quota } \\
\text { 2. Easy to use } \\
\text { 3. The feature is quite complete } \\
\text { 4. Synchronous automatic contact } \\
\text { 5. Video call quality is good } \\
\text { 6. It does not require friendship } \\
\text { approval } \\
\text { 7. Easy to create a group } \\
\text { 8. Can reduce the file size } \\
\text { 9. No ads } \\
\text { 10. Can share various files } \\
\text { 11. Can share locations } \\
\text { 12. user friendly (Zakirman \& Rahayu, } \\
\text { 2018) }\end{array}$ & $\begin{array}{l}\text { 1. Frequent misuse of information } \\
\text { 2. There was a force close on } \\
\text { some devices } \\
\text { 3. User must add contact first } \\
\text { 4. Cannot send large files } \\
\text { 5. Join the group without } \\
\text { confirmation (Zakirman \& } \\
\text { Rahayu, 2018) } \\
\text { 6. Group voice/video calls are } \\
\text { limited to a maximum of } 8 \\
\text { people }\end{array}$ \\
\hline
\end{tabular}




\begin{tabular}{|c|c|c|c|c|c|}
\hline 2 & $\begin{array}{l}\text { Zoom } \\
\text { Cloud } \\
\text { Meeting }\end{array}$ & $\begin{array}{l}1 . \\
2 . \\
3 .\end{array}$ & $\begin{array}{l}\text { Flexible } \\
\text { Provides several features that } \\
\text { support learning } \\
\text { Improve the discipline of lecturers } \\
\text { and students (Mubarak et al., } \\
2020 \text { ) }\end{array}$ & $\begin{array}{l}1 . \\
2 .\end{array}$ & $\begin{array}{l}\text { Time restrictions for free users } \\
\text { (Mubarak et al., 2020) } \\
\text { Requires a stable internet } \\
\text { network } \\
\text { Requires quite a lot of internet } \\
\text { quota }\end{array}$ \\
\hline 3 & YouTube & $\begin{array}{l}1 . \\
2 . \\
3 .\end{array}$ & $\begin{array}{l}\text { Can rewind the playing video } \\
\text { (Tutiasri et al., 2020) } \\
\text { A wide selection of videos } \\
\text { Can choose the image quality of } \\
\text { the playing video }\end{array}$ & $\begin{array}{l}1 . \\
2 .\end{array}$ & $\begin{array}{l}\text { One-way communication } \\
\text { Interaction can be done only } \\
\text { through the comment feature }\end{array}$ \\
\hline 4 & $\begin{array}{l}\text { E- } \\
\text { Learning } \\
\text { Moodle }\end{array}$ & $\begin{array}{l}1 . \\
2 . \\
3 . \\
4 .\end{array}$ & $\begin{array}{l}\text { Open-source or free } \\
\text { Easy installation process } \\
\text { Neat teaching structure } \\
\text { There are quiz facilities, } \\
\text { assignments, and scoring that can } \\
\text { be arranged as needed } \\
\text { There is a themes menu that } \\
\text { makes it easier for users to adjust } \\
\text { the display (Kurniawan, 2009) }\end{array}$ & $\begin{array}{l}2 . \\
3 .\end{array}$ & $\begin{array}{l}\text { Not user-friendly, unreliable, } \\
\text { and unclear process } \\
\text { Weak user guide, so user } \\
\text { understanding is not optimal } \\
\text { Slow access time due to small } \\
\text { bandwidth and poor design of } \\
\text { materials that have large file } \\
\text { sizes (Setiawan, 2006) }\end{array}$ \\
\hline
\end{tabular}

Several previous studies have discussed online Arabic learning in terms of learning methods (Anah, 2020; Zulaini et al., 2020), learning strategy (Syarif, 2020), and the obstacles faced by teachers (Anah, 2020; Zulaini et al., 2020) and students (Corinna et al., 2020). In particular, other previous studies related to WhatsApp more focused on the roles (Abidah, 2020), functions, and benefits of using WhatsApp in online learning such as overcoming the limitations of space and time, as happened during this pandemic (Adlani \& Hanifah, 2020; Genitri, 2019), increasing students' learning motivation (Susilawati \& Supriyatno, 2020), supporting students to integrate videos, messages, images, texts, and audio file (Barhoumi, 2020), and support the teaching and learning process with the available features (Wahyuni, 2018).

In a study by Mustafa, it was stated that Whatsapp has group services that are able to make learning more fun by discussing certain themes given by the teacher. Therefore, a pleasant learning atmosphere will increase the motivation of students in learning (Mustofa, 2020). WhatsApp application is also an effective learning media in teaching the four Arabic language skills (speaking, listening, writing, reading) based online (Rachmayanti \& Alatas, 2020). Other research shows that it is necessary to look at the condition of students when teachers want to use Whatsapp media. When used in the learning process between lecturers and students, or aliyah students, it can be effective because it is supposed to be in the form of discussion (Prananingrum \& Kholis, 2020). via Whatsapp media, teachers take advantage of the WhatsApp group feature to interact, discuss and ask questions answer about the material presented in Arabic (Prasetya, 2020).

These benefits of using WhatsApp in the implementation of online Arabic learning need to be balanced with knowledge related to obstacles, challenges, and efforts to avoid repeating the same mistakes in the future. Therefore, researchers took the initiative to 


\section{A. Syahid Robbani et al.}

complement previous studies in examining the challenges of using WhatsApp as an online Arabic learning center.

\section{B. Research Methodology}

The type of this research is field research using a qualitative approach and descriptive method. The descriptive research method in this study was used to describe the implementation of online Arabic learning in class VII PPS Madrasah Qur'an Nurul Hakim Kediri, West Lombok, which was centered on the WhatsApp application.

The data in this study were obtained through direct observations by participating in the WhatsApp Group, which was used as an online Arabic learning center for seventhgrade in PPS Madrasah Qur'an Nurul Hakim Kediri, West Lombok, which consists of 2 Arabic language teachers and 71 students. In addition, data were also obtained through semi-structured interviews with two Arabic language teachers and five seventh-grade students of PPS Madrasah Qur'an Nurul Hakim Kediri, West Lombok. Snowball sampling technique was used in determining the students as participants. Semi-structured interviews began with two students at first. Then the researcher conducted another interview with other students who were considered able to complete the data provided by the two previous students.

The data analysis technique used in this research is a qualitative descriptive data analysis technique. Researchers carried out data analysis and data collection by paying attention to the stages of the data analysis process, namely the data collection, data condensation, data display, and verification or withdrawal of conclusion (Miles et al., 2014).

\section{Findings and Discussion}

\section{WhatsApp as an Online Arabic Learning Center}

The information contained in the online learning schedule of PPS Madrasah Qur'an Nurul Hakim Kediri, West Lombok, it is stated that: (1) learning using WhatsApp Group; (2) all subject teachers to prepare learning module files for each meeting; (3) all subject teachers to make written reports of evidence for learning activities. This implementation of online Arabic learning using WhatsApp is also based on complaints and input from student parents to teachers not to use online, face-to-face media like zoom from morning to evening because at that time, the student parents bring the smartphones for work. To overcome this limitation, the teacher uses videos from Instagram live to remove the constraints of online Arabic learning in using face-to-face online media. That way, the teacher's explanations related to the core of the subject matter can still be watched, heard, and paid attention to directly by students.

Some of the things that have become the focus of researchers in the use of WhatsApp Group in the implementation of online learning in seventh-grade PPS Madrasah Qur'an Nurul Hakim Kediri West Lombok are: 
Table 2: WhatsApp Group as An Online Learning Center

WhatsApp Groups were made into classes, namely seventh-grade and eighth-grade,
where seventh-grade in offline learning was divided into two classes, namely seventh-
grade A and seventh-grade B, with a total of 71 students. However, the two classes were
combined into one WhatsApp group named "Kelas Daring I MONH Pa" in online
learning.
The WhatsApp Group was not only filled by students and teachers but also by some
parents or guardians of the students who do not have smartphones to access learning
via WhatsApp.
One WhatsApp group was used for all subjects studied by seventh-grade students. So,
no other groups were used for online learning, or no other WhatsApp groups were
created according to their respective subjects, such as WhatsApp groups for Arabic
learning, WhatsApp groups for social studies learning, or WhatsApp groups for science
learning. The division of groups based on subjects like this will undoubtedly make it
easier for students and teachers to focus on their respective subjects, discuss more
deeply, and share learning information that is not mixed up with other subjects.
The Whatsapp group "Kelas Daring 1 MONH Pa" is only managed by an admin
consisting of subject teachers. It means that only group members who are admins
(teachers) can send messages, photos, videos, and other files. This WhatsApp group
management policy for online learning does not seem to provide space for students to
express opinions or ask questions directly related to learning material in the group.
Likewise, interaction in learning activities (via the WhatsApp group) between students
and teachers and between students and students will be complicated. Students must
contact the teacher or other friends directly through private chat to ask questions and
discuss when they encounter difficulties in learning.

Online Arabic learning for seventh-grade VII PPS Madrasah Qur'an Nurul Hakim was conducted by combining the available WhatsApp Group with audio and video uploaded to Google Drive, Instagram, and YouTube. The learning method used is the assignment method. The steps for implementing online Arabic learning in seventh-grade PPS Madrasah Qur'an Nurul Hakim Kediri, West Lombok was the teachers sending a chat into the WhatsApp Group containing subject name, the learning materials to be studied during the lesson, the date of the implementation of the learning activities, teacher's name, a YouTube link or a Google Drive link that contains material or explanation of material that is in accordance with the learning material to be taught during the lesson, examples of learning materials accompanied by assignments that students must complete, as well as steps for collecting assignments. It also contains an explanation of ethics in contacting teachers for assignment collection.

The information that the researcher obtained from direct observation of the media and learning methods used in online Arabic learning was confirmed by the seventh-grade Arabic teacher of PPS Madrasah Qur'an Nurul Hakim Kediri, West Lombok, in his interview. Furthermore, the teacher explained that the media used in online Arabic learning were audio, visual (photo), and audiovisual (video) media. A book or muqarrar accompanies audio and video in the form of a pdf sent to students via WhatsApp Group. This pdf muqarrar book contains several pictures or photos of the material in the book used 


\section{A. Syahid Robbani et al.}

in learning activities, namely 'Durusul Lughah.' This book must be owned by seventh-grade students PPS Madrasah Qur'an Nurul Hakim Kediri, West Lombok. The order of chapters and the selection of material provided in online Arabic learning is in accordance with the order and material in the Durusul Lughah book. Teachers usually include photos or pdf files containing material from books because teachers are worried that not all students will take their books home. Maybe some are left in the boarding school, so they can see directly from the photos or pdf files sent by the teachers. Likewise, the assignments given by the teachers are sometimes taken from the book, in addition to the questions made by the teachers by referring to the book.

Apart from the Durusul Lughah book, the teachers admitted that the students used no other books or books. If the teachers use videos from YouTube in online Arabic learning, the teacher generally gives the subject matter, not taking it from the book. The teacher gave an example of online Arabic learning about dlomir muttashil, the teachers took material from YouTube in general but still adapted it to what was in the book.

Meanwhile, Google Drive was used to send large files and be easy to use. Only by uploading files in the form of audio, video, or others, then the Google Drive link was shared. Students then can open the shared link through the Google Drive application directly or through their browser. Teachers also did not need to convert large files to match the provisions on WhatsApp.

The audio media used by the teachers was not voice notes feature which available on the WhatsApp application, but voice recordings using the voice recorder application. The voice recording is then shared through the WhatsApp Group or by uploading it via Google Drive first, and then the Google Drive link is shared through the WhatsApp Group. The teachers have not used the voice note feature in the WhatsApp application because it is prone to be canceled. The record button for voice notes is often released and causes the deletion of the voice recording that has been made.

Another media used in online Arabic learning was Instagram. In this Instagram application, teachers take advantage of the live feature to make videos that contain explanations about the subject matter and assignments that students have to do. The video will then be saved on the personal teacher's Instagram account, and the video link will be shared through the WhatsApp group for students to watch. Making videos on the Instagram application was chosen as one of the media in online Arabic learning because students can directly see the explanation video from the teacher, pay attention, and understand what is explained. Another reason for the teachers making videos on this Instagram application was as an alternative to the difficulty of using face-to-face online media in online Arabic learning for seventh-grade PPS Madrasah Qur'an Nurul Hakim. Although students cannot communicate directly in practice, at least students can see and hear the teacher's explanation directly from the video. So, it was hoped the understanding that students get could be better. According to the teacher, some seventh-grade students already have personal Instagram accounts, as seen from the number of students who follow the teacher's Instagram account with their accounts. The teacher then uses this by carrying out online Arabic learning using Instagram. 
At each meeting, the teachers included several questions that were tasks for students to do based on the explanations contained in the voice and video recordings made by the teacher and videos taken from YouTube. The task consists of 5-6 questions and must be done at 22.00 WITA on the same day. The task was done on each student's book then pictured and sent to the teacher's WhatsApp directly.

The assignment method was used by Arabic language teachers in seventh grade as student attendance in online Arabic learning. Students who submitted the assignments by sending them to the teacher's WhatsApp were considered present, while students who did not submit the assignments were considered absent. This assignment method also serves as an indicator for teachers, whether students pay attention to the learning materials or not. Because in the online Arabic learning that was carried out, the teacher found students who sent answers that were not appropriate and even different from the explanations in the audio and video provided by the teacher. According to the teacher, this indicates that the students did not read and learn the material provided and the answer was obtained through browsing or googling from the internet. The teachers also see how serious the students are in participating in online Arabic learning through this assignment method.

The steps taken by the teachers in online Arabic learning based on WhatsApp and learning methods mentioned above can be seen in the following table:

\section{Table 3: Online Arabic Learning Steps Based on WhatsApp Conducted by Teachers}

The teachers made a voice recording using the voice recorder application. The voice recording contains an explanation of the subject matter that will be studied at the

1 meeting. After making a voice recording, the teachers then prepare 5-6 questions as

assignments that students must do. When the online Arabic learning lesson has arrived, the teachers then chat to the WhatsApp Group to start learning. The chat includes a Google Drive link containing voice recordings and assignments for students to do.

The teachers recorded a video explaining the subject matter and then uploaded it to Google Drive. After that, the teachers prepared several questions as assignments that students must do. Then the teachers shared a Google Drive link containing videos and assignments that have been prepared to students via chat in the WhatsApp Group.

The teachers look for videos related to learning materials on YouTube. The teachers tried to find the best videos that contain concise and easy-to-understand explanations, the duration is not too long, and the most exciting videos. The selection of videos like this aims to attract students' attention so that students become curious about the video, do not get bored with the explanation, increase enthusiasm for learning, and the most important thing is that students understand the explanation in the video. After finding the appropriate video, the teacher shares the video link accompanied by assignments containing several questions.

The provision of Arabic language subject matter in the form of mufrodat (vocabularies) was sent via WhatsApp Group, and then the students were assigned to memorize the vocabularies. After that, the students deposited the mufrodat memorization by making a

4 short video then sent it to the teachers. To make it easier for students to pronounce these vocabularies, the teachers give an example of pronouncing these mufrodat through the Voice Note feature. 


\section{A. Syahid Robbani et al.}

is stored on the teachers' Instagram account, named 'Materi Daring Kelas 1 '. The Instagram live video contains a direct explanation from the teachers about the subject matter and assignments that must be completed. The link from the video is then copied and sent to the WhatsApp Group when the online Arabic lesson begins. Later the video can be opened directly through the WhatsApp application or by switching to Instagram.

At one of the online Arabic learning meetings, the teacher asked permission from other teachers to open a WhatsApp group. Students could chat directly into the group

6 (previously, only admins/teachers could send chats or files to the group). The teacher sends a picture of the subject matter containing a conversation, and the students are divided into pairs. Students are then asked to practice the existing conversation through the Voice Note feature.

The assignment method becomes a method that has been presented in every series of online Arabic learning steps carried out by teachers as described above. Regarding the type of assignment used, teachers prefer individual assignment types by emphasizing coaching on the affective, cognitive, and psychomotor aspects of students individually (Susanti et al., 2020). This assignment method aims to increase students' knowledge, train students to learn independently, discipline, and utilize time regularly (Hamalik, 2003), as well as foster student initiative and a sense of responsibility (Roestiyah, 2007). Nevertheless, the teacher still should watch the use of this assignment method because it can affect students' mood change if the task is too much (Irawan et al., 2020). Student mood becomes an essential thing in a learning process because it can affect the motivation and spirit of learning students. The motivation can then affect the learning outcomes obtained by students. Therefore, teachers should combine this assignment method with other methods that can maintain and even increase student learning motivation, especially in online learning limited to WhatsApp.

\section{Challenges in Using WhatsApp as an Online Arabic Learning Center}

Students then study the learning material provided by the teachers through the media above in their way. Based on interviews with students, students learn the material provided by watching videos that are shared either through YouTube or Instagram. In addition, students also memorize the vocabularies then deposit the memorization of the vocabularies by making a video. However, according to students, the material shared was sometimes still difficult to understand. Because for students, it will be easier to understand the lesson if they listen to the explanation directly (face to face), students can ask directly to the teachers when they do not understand. This students' perceived challenge is in line with participants' state in Song et al. (2004) study, who indicated that the difficulty in understanding online learning objectives is a challenge. This is also why students prefer to study the material provided through Instagram because the videos contain direct explanations from the teacher, while the videos on YouTube were usually taken from existing channels. In addition to the difficulty in online Arabic learning through WhatsApp, students also feel that the vocabularies obtained from online Arabic learning are often forgotten because the vocabularies cannot be practiced directly by students at home. 
In contrast to the case at the boarding school, students can immediately practice the vocabularies that were obtained in their daily lives. In connection with the internet quota needed in the implementation of online Arabic learning centered on the WhatsApp application, this was usually widely used by teachers to upload subject matter to Google Drive or share it on WhatsApp Group directly in the form of voice recordings, pdf files containing photos, and videos. Likewise, downloading photos containing assignments submitted by students.

Other challenges and some of the efforts made to overcome them can be seen in the following table:

Table 4: Challenges in Using WhatsApp as An Online Arabic Learning Center

\begin{tabular}{lll}
\hline No & \multicolumn{1}{c}{ Challenges } & \multicolumn{1}{c}{ Efforts } \\
\hline $\mathbf{1}$ & $\begin{array}{l}\text { There is a maximum file size limit sent } \\
\text { through the WhatsApp application, } \\
\text { which is a maximum of } 16 \mathrm{MB}\end{array}$ & $\begin{array}{l}\text { The teachers convert the file before } \\
\text { sending or by uploading the file to Google } \\
\text { Drive first }\end{array}$ \\
\hline $\mathbf{2}$ & $\begin{array}{l}\text { Some students have not joined the } \\
\text { WhatsApp Group. }\end{array}$ & $\begin{array}{l}\text { The teachers coordinate with the } \\
\text { homeroom teacher to look for the student } \\
\text { phone numbers who have not entered the } \\
\text { WhatsApp group }\end{array}$ \\
\hline $\mathbf{3}$ & $\begin{array}{l}\text { Teachers find it difficult to optimize the } \\
\text { learning method, especially in } \\
\text { determining the level of questions }\end{array}$ & $\begin{array}{l}\text { The teachers lower the level of the } \\
\text { questions given as assignments to students }\end{array}$ \\
\hline $\mathbf{4}$ & $\begin{array}{l}\text { Teachers face difficulty in controlling } \\
\text { and supervising students in studying the } \\
\text { learning material provided }\end{array}$ & $\begin{array}{l}\text { The teachers check the accuracy of the } \\
\text { assignments submitted by students }\end{array}$ \\
\hline $\mathbf{5} \quad \begin{array}{l}\text { Unfavorable online Arabic learning } \\
\text { process when the teacher opens a } \\
\text { WhatsApp group for students }\end{array}$ & $\begin{array}{l}\text { The teacher reprimands students who } \\
\text { make online Arabic learning through } \\
\text { WhatsApp groups unfavorable. }\end{array}$ \\
\hline $\mathbf{6} \quad \begin{array}{l}\text { Internet network problems for some } \\
\text { students to open materials on YouTube } \\
\text { or Instagram, especially when it rains. }\end{array}$ & $\begin{array}{l}\text { Students use their parents' smartphones } \\
\text { who have a better internet connection to } \\
\text { open the learning material provided }\end{array}$ \\
\hline
\end{tabular}

The maximum size limit of files sent through the WhatsApp application, which is a maximum of $16 \mathrm{MB}$, is the same as a video with 90 seconds to 3 minutes duration, depending on the camera quality of each smartphone. At the same time, the audio and video created by the teachers have a file size larger than the maximum file size that can be sent via WhatsApp. For example, the audio file size created by the teachers was 30-40 MB. To overcome this file size limitation, the teacher converts the file so that the size of the file to be sent can be reduced to 8-10 MB. Another way that teachers use to solve this problem is to use Google Drive. Google Drive provides 15 GB of free storage space for the user, which is a much larger capacity than files that can be sent via WhatsApp. By using Google Drive, teachers can be more flexible in uploading learning files in various forms.

Concerning the problems related to several students who have not yet joined the WhatsApp Group, the teachers try to coordinate with the homeroom teachers of seventhgrade $A$ and $B$ to look for their numbers or contacts and register them to participate in 


\section{A. Syahid Robbani et al.}

online Arabic learning like other students. This becomes very important considering that online Arabic learning is centered on WhatsApp Group.

On the other hand, even though the teachers only use the assignment method in online Arabic learning through WhatsApp, they find it challenging to optimize the learning method. One reason is that the teachers cannot explain the learning material perfectly like the learning done in class (face-to-face learning). In addition, the teachers also have difficulty in determining the level of questions that will be used as assignments for students, whether the questions given are too high or maybe too low for online learning of Arabic. In order to deal with this, the teachers chose to lower the level of the questions given as assignments to students. What is more important for teachers is how students want to participate in online Arabic learning and work on existing tasks. The decrease in the level of questions is in line with the students' answers in their interviews regarding the difficulty of the tasks given in online Arabic learning, who said that the questions given were relatively easy.

With WhatsApp as an online Arabic learning center and the assignment method as the only learning method used, teachers cannot know whether students read and watch the learning material. It can be seen from the presence of some students who asked again through messages to the teachers regarding the assignments given, even though the teacher had given a complete explanation. The teachers usually explain the task at the end of the video and voice recording. In this regard, the teachers look at the accuracy of the assignments that students collect, is the task done following the order or not. Because there are students who do not work following orders. The teachers give assignments on one page, but students work on assignments on another page. According to the teacher, this indicates that the students did not read and watch the learning material well. The constraints of validation of student assignments in online learning will undoubtedly make it difficult for teachers to evaluate the learning outcomes (Bariah \& Imania, 2017).

Next is the unfavorable online Arabic learning process when the teacher opened the WhatsApp group for students. When the teacher explained the following material or gave a new order, some students just sent what was previously ordered by the teacher. In addition, some students interrupt the teacher's message explaining the material, such as by calling his friend's name with a voice note. To overcome this problem, teachers need to create good, familiar, and profitable relationships, especially in academic situations, by recognizing their students, being open, trusting, and appreciative, and teachers must have sincerity in guiding their students, as well as students must be sincerely guided by their teachers (Madjid, 2016).

From the discussion above, it can be concluded that the challenges and obstacles faced in the use of WhatsApp as an online Arabic learning center in PPS Madrasah Qur'an Nurul Hakim Kediri, West Lombok include the number of students who are quite a lot in one WhatsApp Group, namely 71 students, restrictions on file sizes that can be sent through WhatsApp, the presence of students who have not entered the WhatsApp Group, challenges in determining the level of difficulty of assignments to be given to students, difficulties in controlling students thoroughly, and not conducive to the learning situation 
with students sending voice notes that are not in accordance with what is directed by the teacher. The challenges and constraints found by researchers in this study are slightly different from the obstacles experienced by participants from research conducted by Laelasari \& Dewi (2020) mention that students have not been able to use the WhatsApp application, send assignments, and work on problems through the application. In other studies, there are also some shortcomings owned by the WhatsApp application, such as constraints in the implementation of face-to-face online and the absence of features to limit task time (Bhagaskara et al., 2021). The above findings related to the challenges and constraints in the use of WhatsApp in learning become complementary to each other, so it is expected to be able to provide more in-depth information to WhatsApp users, especially in the context of learning. The findings in this study and relevant research related to teachers' and students' constraints, shortcomings, and needs in carrying out online learning through WhatsApp became the basis of researchers to propose the development of WhatsApp for Education as WhatsApp for Bussiness has been circulating so far.

\section{Conclusion}

Finally, the result of this research showed that students and teachers face several challenges and obstacles in using WhatsApp as an online Arabic learning center, such as the maximum size of files that can be sent through the WhatsApp application, there are some students who have not joined the WhatsApp Group, the difficulty of teachers in delivering learning materials perfectly as in offline Arabic learning, difficulty in determining the level of questions to be given in the assignment, difficulty in using other learning media such as zoom meeting, the difficulty of the teacher in fully controlling the students, the unfavorable situation when the teacher opens the WhatsApp Group for students, and internet network constraints for some students. In overcoming some of these challenges and obstacles, students and teachers made several efforts, including the teachers converting the learning material file or uploading it first to Google Drive and then sharing the link to the students through WhatsApp Group, the teacher lowered the level of the questions given in the assignment, and the student control is carried out by looking at the accuracy of the tasks collected by students. Finally, by looking at the role of the WhatsApp application in the current learning process, the researcher hopes that the WhatsApp application developer will consider providing WhatsApp for Education like WhatsApp for Business which has existed for a long time. On the other hand, researchers also suggest further research to examine the proportionate ratio of students in online Arabic learning using WhatsApp.

\section{BIBLIOGRAPHY}

Abidah. (2020). Peran Aplikasi WhatsApp sebagai Media Pembelajaran dalam Mata Kuliah Metodologi Penelitian. Bidayah: Studi Ilmu-Ilmu Kelslaman, 11(1), 87-99. https://doi.org/https://doi.org/10.47498/bidayah.v11i1.311

Adlani, N., \& Hanifah, M. (2020). Media Alternatif Whatsapp (WA) Mengatasi Permasalahan Pembelajaran pada Situasi Pendemi Covid 19 di Kelas PGMI Semester 


\section{A. Syahid Robbani et al.}

IV. At-Thullab Jurnal Pendidikan Guru Madrasah Ibtidaiyah, 4(2), 93-110.

Anah, S. (2020). Pembelajaran Bahasa Arab Daring (Studi Kasus Mahasiswa Hukum

Keluarga Islam (HKI) STAI Taruna Surabaya. Jurnal Al-Fakkar, 1(1), 18-41.

Barhoumi, C. (2020). The Effectiveness of WhatsApp Mobile Learning Activities Guided by

Activty Theory on Students' Knowldege Management. Contemporary Educational Technology, 6(3), 221-238. https://doi.org/10.30935/cedtech/6151

Bariah, S. H., \& Imania, K. A. N. (2017). Pengembangan Evaluasi Dan Penugasan Online

Berbasis E-Learning Dengan Moodle Pada Mata Kuliah Media Pembelajaran Ilmu Komputer. Jurnal Nasional Pendidikan Teknik Informatika (JANAPATI), 6(3), 305-315. https://doi.org/10.23887/janapati.v6i3.12458

Bhagaskara, A. E., Nur Afifah, E., \& Maulana Putra, E. (2021). Pembelajaran dalam Jaringan (DARING) Berbasis WhatsApp di SD Yapita. ZAHRA: Research and Tought

Elementary School of Islam Journal, 2(1), 13-23. https://doi.org/10.37812/zahra.v2i1.183

Corinna, D. F., Rembulan, I., \& Hendra, F. (2020). Problematika Pembelajaran Bahasa Arab

Secara Daring: Studi Kasus Mahasiswa Program Studi Bahasa dan Kebudayaan Arab Universitas Al-Azhar Indonesia. Prosiding Konferensi Nasional Bahasa Arab VI, 569578.

Genitri, W. (2019). Grup WhatsApp Sebagai Media Pembelajaran. Jurnal Ilmiah Pendidikan, $\begin{array}{llll}\text { Agama Dan Kebudayaan Hindu, 53-62. } & \text { 10(2), }\end{array}$

https://doi.org/https://doi.org/10.36417/widyagenitri.v1oi2.281

Hamalik, O. (2003). Proses Belajar. Bumi Aksara.

Irawan, A. W., Dwisona, D., \& Lestari, M. (2020). Psychological Impacts of Students on

Online Learning During the Pandemic Covid-19. KONSELI: Jurnal Bimbingan Dan Konseling (E-Journal), 7(1), 53-60. https://doi.org/10.24042/kons.v7i1.6389

Kurniawan, R. (2009). Membangun Media Ajar Online untuk Orang Awam. Maxikom.

Laelasari, I., \& Dewi, N. P. (2020). Penerapan Pembelajaran Daring Berbasis Whatsapp

Group Untuk Siswa Madrasah Ibtidaiyyah di Tengah Pandemi Covid-19. Jurnal

Penelitian, 14(2), 249-268. https://doi.org/10.21043/jp.v14i2.8447

Madjid, A. (2016). Strategi Pembelajaran. Remaja Rosdakarya.

Miles, M. B., Huberman, A. M., \& Saldana, J. (2014). Qualitative Data Analysis: A Methods Sourcebook. SAGE Publications

Mubarak, M. R., Wahdah, N., Ilmiani, A. M., \& Hamidah. (2020). Zoom Cloud Meeting: Media Alternatif dalam Pembelajaran Maharah Kalam di Tengah Wabah Virus Corona (Covid-19). Arabiyatuna Jurnal Bahasa Arab, 4(2), 211-226.

Mustofa, M. A. (2020). Analisis Penggunaan WhatsApp Sebagai Media Pembelajaran

Bahasa Arab di Era Industri 4.0. Arabiyatuna: Jurnal Bahasa Arab, 4(2), 333. https://doi.org/10.29240/jba.v4i2.1805

Prananingrum, A. V., \& Kholis, M. N. (2020). Whatsapp sebagai Media Pembelajaran Bahasa Arab pada Masa Pandemic Covid-19. Proceeding NATHLA : Al-Nadwah Al'Alamiyyah Fi Ta'Lim Al-Lughah Al-'Arabiyyah (International Conference on Arabic Languange Teaching), 129-136. index.php/natla/article/view/166

Prasetya, N. (2020). Pembelajaran Bahasa Arab Pada Murid Melalui Aplikasi Whatsapp. 
Challenges in Using WhatsApp as An Online Arabic Learning Center

Multaqa Nasional Bahasa Arab, 3, 44-70.

http://munasbauai.com/index.php/mnba/article/view/8o

Rachmayanti, I. \& Alatas, M.A. (2020). Pemanfaatan Aplikasi Whatsapp Sebagai Media

Pembelajaran Bahasa Arab Berbasis Daring Pada Masa Pandemi Covid-19, Prosiding

KNPI: Konferensi Nasional Pendidikan Islam, 361-77.

Roestiyah. (2007). Strategi Belajar Mengajar. Rineka Cipta.

Setiawan, W. (2006). Pembelajaran Berbasis ICT: Model E-learning Menggunakan Opensource Moodle, dalam buku Mimbar Pendidikan. UPI Press.

Song, L., Singleton, E. S., Hill, J. R., \& Koh, M. H. (2004). Improving online learning: Student perceptions of useful and challenging characteristics. Internet and Higher

Education, 7(1), 59-70. https://doi.org/10.1016/j.iheduc.2003.11.003

Sukamto, Elfizar, \& Asriyani. (2017). Media Pembelajaran Bahasa Arab untuk Siswa

Madrasah Ibtidaiyah. Jurnal Edukasi Dan Penelitian Informatik (JEPIN), 3(2), 104-110.

https://doi.org/https://dx.doi.org/10.26418/jp.v3i2

Sukiman. (2010). Pengembangan Media Pembelajaran. Pustaka Insan Mada.

Susanti, B., Juniardi, Y., \& Irmawanty. (2020). Meningkatkan Pemahaman Pembelajaran

Denah Melalui Metode Penugasan Pada Siswa Kelas 5 Ibtidaiyah. 2020: Prosiding

Seminar Dan Diskusi Nasional Pendidikan Dasar "Transformasi Pendidikan

Menyongsong SDM Di Era Society 5.0," 1-10.

Susilawati, S., \& Supriyatno, T. (2020). Online Learning Through WhatsApp Group in Improving Learning Motivation in the Era and Post Pandemic Covid-19. Jurnal Pendidikan, 5(6), 852-859.

Syarif, M. U. (2020). Pembelajaran Bahasa Arab Daring Berbasis Strategi Karrona di Masa Pandemi Covid-19. Didaktika: Jurnal Kependidikan, 14(2), 116-132.

Tutiasri, R. P., Laminto, N. K., \& Nazri, K. (2020). Pemanfaatan Youtube sebagai Media Pembelajaran bagi Mahasiswa di Tengah Pandemi Covid-19. Jurnal Komunikas, Masyarakat, Dan Keamanan (KOMASKAM), 2(2), 1-15.

Wahyuni, N. (2018). Peran Penggunaan Grup WhatsApp dalam Proses Belajar Mengajar Di SMK Negeri 2 Banjarmasin. Jurnal Mutakallimin, 1(2), 19-26.

Zakirman, \& Rahayu, C. (2018). Popularitas Whatsapp sebagai Media Komunikasi dan Berbagi Informasi Akademik Mahasiswa. Shaut Al-Maktabah Jurnal Perpustakan, Arsip, Dan Dokumentasi, 10(1), 27-38.

Zulaini, N. N., Mufidah, N., Kholis, N., \& Amrulloh, M. A. (2020). Pembelajaran Bahasa Arab untuk Madrasah Ibtidaiyah pada Masa Wabah Covid-19. Jurnal Al-Mudarris, 3(1), $39-55$. 